\title{
Technical Performance Evaluation of Small-Scale Irrigation Scheme at Wondo Genet, Ethiopia
}

\author{
Henok Tesfaye \\ Wondo Genet Agricultural Research Center, Ethiopian Institute of Agricultural Research Institute, Irrigation and \\ water harvesting research program, P. O. Box 198, Shashemane, Ethiopia
}

\begin{abstract}
Expanding efficient irrigation development on various scales is one of the best alternatives to provide reliable and sustainable food security. However, many irrigation schemes in developing countries in general and particularly in Ethiopia are performing below capacity. This study was conducted to evaluate the performance of wosha soyama irrigation scheme at Wondo Genet SNNPRS, Ethiopia. The evaluation carried out using standard technical performance indicators including conveyance, application, water storage, water distribution uniformity efficiency and deep percolation ratio were used at the head, middle and tail reach of the scheme. The study shows that application efficiency was very which is $48.2 \%$ due to higher water loss through deep percolation. Conveyance efficiency, water storage, water distribution uniformity efficiency, and deep percolation ratio were revealed 55.6 $89.8,91.7$, and $51.8 \%$, respectively. The overall efficiency was also below the desired level which is $26 \%$. Based on the above observation, adoption of water-saving practices such as deficit irrigation, surge and cutoff application to improving the application, frequent maintains of water conveyance system can enhance the conveyance efficiency of the scheme.
\end{abstract}

Keywords: Irrigation scheme, Performance, evaluation, and technical indicators

DOI: $10.7176 /$ JRDM/68-02

Publication date:August $31^{\text {st }} 2020$

\section{Introduction}

Water is the most limited resource, which is widely used by different sectors like agriculture, water supply, and industrial. Due to the rapid increase in the world population, food demand also increased as well. The competition for this scarce resource is increasing from time to time due to increasing food demand from the highly consuming agricultural sector (Ingle et al., 2015; Pereira et al., 2009).

Worldwide, the cost of water insecurity to the irrigation sector is estimated at about US\$94 billion per year, and hence the total value of water insecurity to the global economy is about US\$500 billion annually (Sadoff $e t$ $a l ., 2015)$. In addition, increasing stress on water resources could inhibit an adaptation effort that increases irrigation development by maintaining the current level of the irrigation system.

Modern irrigation systems in Ethiopia started in the 1960s with the objective of producing industrial crops in Awash Valley (Seleshi et al., 2007). The total irrigable land area in the country is estimated as 5.3 Mha. However, only about 4 to 5 percent is cultivated under irrigation from the existing cultivated area of the country. Which implies that based on the irrigable land potential, only 12\% is under irrigation currently (Seleshi, 2010). However, about $90 \%$ of the irrigation potential in terms of land and water resources has not been developed so far. In recent years, there are many irrigation developments progresses in medium and large-scale. Whereas about $47 \%$ of the developed area is under large-scale public irrigation schemes, mainly industrial crops like cotton, sugarcane, and fruits were grown (Zeleke et al., 2012).

According to FAO (2011) report, irrigated agriculture is the most inefficient and much water consuming sector, which contributes globally about $70 \%$ of water withdrawal from different sources like aquifers, streams, and lakes and it is over $90 \%$ in most of the least developed countries. Without improved efficiency measures, agricultural water consumption is expected to increase by about $20 \%$ globally by 2050 (WWAP, 2012).

The comparative estimate is 40 percent or more of the water diverted for irrigation is wasted at the farm level through either deep percolation or surface runoff (FAO, 1989). As a result, the performance evaluation of irrigation schemes plays a fundamental role in improving the productivity of irrigation schemes by identifying where the critical problem occurred. Therefore, it is reasonable to evaluate the performance of Wosha Soyama small scale Irrigation Schemes found in Wondo Genet District of SNNPRS.

\section{Material and Methods \\ Description of the Study Area}

The study irrigation schemes are found in Wondo Genet district, southern nation, nationality, and people regional state (SNNPRS) of Ethiopia which is located at about $263 \mathrm{~km}$ south of Addis Ababa. Geographically lied from $6^{\circ} 54^{\prime} 0^{\prime \prime}$ to $7^{\circ} 7^{\prime} 45^{\prime \prime} \mathrm{N}$ and $38^{\circ} 31^{\prime} 33^{\prime \prime}$ to $38^{\circ} 41^{\prime} 20^{\prime \prime} \mathrm{E}$ and covers an area with an altitudinal range of 1600 to $1950 \mathrm{~m}$. a.s.l. The scheme has designed to develop 180 ha of the irrigated area at wosha soyama kebele.

Long-term (1986-2015) climatic record of Wondo Genet College of forestry and natural resources 
meteorological station, average annual rainfall in the area is $1069.2 \mathrm{~mm}$. The area receives more than $70 \%$ of the total annual rainfall between Aprils and September. The monthly maximum and minimum rainfall values are 147.0 $\mathrm{mm}$ and $18.3 \mathrm{~mm}$ occurs in the month of August and December, respectively (Table 1).

Table 1. Long-term climatic data of the study area

\begin{tabular}{|c|c|c|c|c|c|c|}
\hline Month & $\begin{array}{l}\mathrm{T} \max \\
(\mathrm{OC})\end{array}$ & $\mathrm{T} \min \left({ }^{\mathrm{O}} \mathrm{C}\right)$ & $\begin{array}{c}\text { Relative } \\
\text { humidity }(\%)\end{array}$ & $\begin{array}{c}\text { Wind speed } \\
(\mathrm{m} / \mathrm{s})\end{array}$ & Sunshine hour & $\begin{array}{c}\text { Rainfall } \\
\text { (mm) }\end{array}$ \\
\hline January & 24.2 & 12.6 & 47.4 & 3 & 8.7 & 28 \\
\hline February & 25.7 & 13.8 & 42.0 & 3.2 & 8.4 & 54 \\
\hline March & 26.2 & 15.1 & 46.4 & 3.3 & 7.9 & 95.6 \\
\hline April & 24.6 & 14.9 & 60.5 & 3.0 & 7.3 & 128.5 \\
\hline May & 23.1 & 14.5 & 71.4 & 2.4 & 7.4 & 115.0 \\
\hline June & 20.9 & 13.8 & 78.8 & 2.9 & 6.7 & 110.9 \\
\hline July & 19.5 & 13.1 & 81.6 & 3.3 & 4.7 & 143.5 \\
\hline August & 19.8 & 13.0 & 81.5 & 3.1 & 5.1 & 147.1 \\
\hline September & 21.0 & 13.1 & 77.9 & 2.3 & 5.5 & 125.2 \\
\hline October & 22.0 & 12.3 & 70.6 & 2.4 & 9.2 & 77.2 \\
\hline November & 23.0 & 11.8 & 58.0 & 3.0 & 9.0 & 26.0 \\
\hline December & 23.2 & 11.9 & 52.1 & 3.1 & 7.2 & 18.3 \\
\hline
\end{tabular}

\section{Data Collection}

All necessary secondary and primary were collected during of 2017/18 irrigation season. To evaluate the study irrigation scheme using technical performance indicators three fields have been selected from the head, middle, and tail end water users with respect to the water source. The selection of fields was done in considering similarly crop and growth stage and the dominance of crop, which most of the schemes land is covered with it.

\section{Soil Texture and Bulk Density}

For textural analysis disturbed soil samples and undisturbed soil for bulk density were collected from each scheme at three locations along diagonal of the selected fields of each scheme (head, middle, and tail end) using soil auger and core sampler with the depths 0-30cm, 30-60 cm, 60-90 cm, and 90-120 cm.

The hydrometer method was used for textural analysis. The bulk density was determined using the following equation (Jaiswal, 2003).

$$
B D=\frac{W_{S}}{V_{c}}
$$

Where:-BD is soil bulk-density $\left(\mathrm{g} / \mathrm{cm}^{3}\right)$,

$\mathrm{W}_{\mathrm{s}}$ is mass of dry soil $(\mathrm{g})$ and

$\mathrm{V}_{\mathrm{c}}$ is volume of soil in the core $\left(\mathrm{cm}^{3}\right)$

\section{Field Capacity and Permanent Wilting Point}

Soil sample for determination of moisture content at field capacity (FC) and permanent wilting point (PWP) was collected at 0-30 cm, 30-60 cm, 60-90 cm, and 90-120 cm from three locations along the diagonal of the selected field of each scheme. The FC and PWP were determined using pressure pate apparatus at 1/3 and 15 bars pressure for field capacity and permanent wilting point, respectively.

The volumetric total available water (TAW) was calculated based on the data of FC, PWP, and root depth using the following equation (Allen et al., 1998).

$\mathrm{TAW}=1000 \sum\left(\theta_{\mathrm{FC}}-\theta_{\mathrm{PWP}}\right) * \mathrm{Z}_{\mathrm{d}}$

Where TAW is volumetric total available water in the root zone $(\mathrm{mm} / \mathrm{m})$,

$\mathrm{Z}_{\mathrm{d}}$ : - root depth $(\mathrm{m})$,

$\theta_{\mathrm{FC}}$ : - volumetric moisture content at field capacity $\left(\mathrm{m}^{3} / \mathrm{m}^{3}\right)$, and

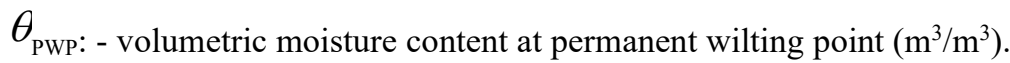

\section{Soil Moisture Determination}

Determine the moisture content of the soil before and after irrigation was determined by the gravimetric method. Soil samples were collected with a $30 \mathrm{~cm}$ interval up to $120 \mathrm{~cm}$. The water content in the soil was determined in the volume base using the following equation (Jaiswal, 2003).

Where: -

$$
\theta_{\mathrm{v}}=\theta_{m} \times B D
$$

$$
\theta_{\mathrm{v}}:- \text { volumetric moisture content in }(\%) \text {, }
$$


BD: - soil bulk density $\left(\mathrm{g} / \mathrm{cm}^{3}\right)$, and

\section{Flow Measurement}

Two-inch Parshall flume was used to determine the amount of water applied by the irrigators to the field where at the head, middle and tail during an irrigation event. Parshall flume was installed at the entrance of the selected farmers' field at the part, which is straight and uniform.

The relationship between the head of irrigation water and its discharge is based on the following equation (USBR, 2014).

Where: -

$$
Q=C * H^{n}
$$

$\mathrm{H}$ :- is water depth measured at one third from in late of converging,

$C$ and $n$ are constants to be determined for flume with two-inch throat

Determination of flow velocity through main, and secondary canals was obtained by floating methods then discharge of the flow was determined by the continuity equation as follows.

Where: -

$$
Q=A V
$$

$$
\begin{aligned}
& \text { Q: - Discharge of the flow }\left(\mathrm{m}^{3} / \mathrm{s}\right) \\
& \text { A: - cross-sectional area }\left(\mathrm{m}^{2}\right) \\
& \mathrm{V} \text { : - Velocity of the flow }(\mathrm{m} / \mathrm{s})
\end{aligned}
$$

However, the measured velocity was multiplied by correction factor 0.85 for rough or rocky bottoms and 0.9 for smooth, muddy, sandy, or smooth bedrock conditions as illustrated by Harrelson et al. (1994).

\section{Technical performance indicators}

Technical performance evaluation of the scheme was done on-farm using the following standard indicators.

\section{Conveyance Efficiency (Ec)}

To determine the conveyance efficiency, the flow at main and secondary canals at a hundred-meter interval recorded using the area velocity method. The second measurement was also taken at a fixed distance above the downstream end of the main and secondary canal.

The conveyance efficiency was computed using the following equation (Michael, 2008).

$$
\mathrm{Ec}=\left(\frac{Q_{\text {in }}}{Q_{\text {out }}}\right) \times 100
$$

The overall conveyance efficiency of the schemes was computed using the following equation.

$$
E c=E m * E S
$$

Ec: - conveyance efficiency $(\%)$,

Em: - conveyance efficiency of the main canal (\%),

Es: - conveyance efficiency of secondary canal (\%),

Losses in conveyance system were computed as;

Where: -

$$
\mathrm{Lc}=Q_{\text {in }}-Q_{\text {out }}
$$

Ec: - conveyance efficiency $(\%)$

Lc: - conveyance loss $\left(\mathrm{m}^{3} / \mathrm{sec}\right)$

$\mathrm{Q}_{\text {in }}$ and $\mathrm{Q}_{\text {out }}=$ are the inflow and outflow discharge in specified canal length $\left(\mathrm{m}^{3} / \mathrm{sec}\right)$

\section{Application Efficiency (Ea)}

Application efficiency was computed using the following equation (Michael, 2008):

$$
E a=\frac{W_{s}}{W_{f}} * 100
$$

Where: -

Ea: - application efficiency

$\mathrm{W}_{\mathrm{s}}$ : - average depth water stored in the root zone of the plant

$\mathrm{W}_{\mathrm{f}}$ : - average water delivered to the field (water depth applied to the field)

\section{Storage Efficiency (Es)}

The distribution uniformity was obtained by the relationship given below (Michael, 2008).

Where: -

$$
E_{s}=\frac{W_{s}}{W_{n}} * 100
$$

$\mathrm{E}_{\mathrm{s}}$ : - storage efficiency $(\%)$

$\mathrm{W}_{\mathrm{s}}$ : - water stored in the root zone during irrigation $(\mathrm{mm})$ 
$\mathrm{W}_{\mathrm{n}}$ : - water needed in the root zone prior to irrigation (mm)

The water needed in the root zone prior to irrigation was computed using the following equation (Michael, 2008).

$W_{n}=\sum_{i=1}^{n}\left(\frac{M_{f c i}-M_{b i}}{100}\right) * B D_{i} * D_{i}$

Where: -

$\mathrm{W}_{\mathrm{n}}$ : - net amount of water to be applied during an irrigation $(\mathrm{mm})$

$\mathrm{M}_{\mathrm{fci}}$ : - field capacity moisture content in the $\mathrm{i}^{\text {th }}$ layer of the soil (\%)

$\mathrm{M}_{\mathrm{bi}}$ : - moisture content before irrigation in the $\mathrm{i}^{\text {th }}$ layer of soil (\%)

$\mathrm{BD}_{\mathrm{i}}$ : - bulk density of the soil in the $\mathrm{i}^{\text {th }}$ layer

$\mathrm{D}_{\mathrm{i}}$ : - depth of the soil layer within the root zone $\mathrm{cm}$, and

$\mathrm{n}$ : - number of soil layers in the root zone D

\section{Water Distribution Uniformity (DU)}

The moisture content collected from a different location was arranged in descending order, then the least quarter and the mean computed. Finally, the distribution uniformity was determined by using equation (Walker, 2003)

Where: -

$$
D U=\frac{\bar{X}_{L q}}{\bar{X}_{m}} * 100
$$

$$
\begin{aligned}
& \text { DU: - Water distribution uniformity (\%), } \\
& \begin{array}{l}
\text { Lq }:- \text { the mean of lower-quarter depth of water stored and } \\
\bar{X}_{m} \text { : - the mean depth of all water stored }
\end{array}
\end{aligned}
$$

\section{Deep Percolation Ratio}

The Furrow that practiced in the scheme is closed-end, therefore runoff ratio also neglected, and the evaporation from the soil neglected because it is only a short period after irrigation. The loss of irrigation water beyond the root zone is only through deep percolation. Therefore, deep percolation ratio was calculated by using the following equation (Feyen and Dawit, 1999).

$D P R=100-E a-R R$

Where: -

DPR: - Deep percolation ratio (\%),

Ea: - application efficiency $(\%)$ and

RR: - runoff ratio

Then after, the overall scheme efficiency calculated as the product of conveyance and application efficiency. It was computed using the following formula (FAO, 2002):

Where: -

$$
E p=E c \times E a
$$

Ep: - overall scheme efficiency ( $\%)$,

Ec: - conveyance efficiency (\%) and

Ea: - application efficiency (\%)

\section{RESULTS AND DISCUSSION}

\section{Soil Physical Characteristics of Study Scheme}

The soil textural class of the scheme revealed that clay, sandy loam, and sand at the head, middle, and tail, respectively was dominant soil textural classes at Wosha Irrigation Scheme (Table 2). Physical soil analysis of Wosha Irrigation Scheme showed that average moisture content on a mass base at field capacity (FC) was 37.2, 24.4 and $13.1 \%$ at the head, middle and tail reach, respectively. On the other hand, the mass base moisture content at the permanent wilting point (PWP) was $24.3,12.6$ and $7.4 \%$ at the head, middle and tail reach, respectively, The bulk density values ranged from 1.04 to $1.25 \mathrm{~g} / \mathrm{cm}^{3}$, the result indicated that as the depth goes down the bulk density increased, which implies the soil compactness increased as goes down to deep. The volumetric total available water content (TAW) at $120 \mathrm{~cm}$ of soil depth ranges from 86 to $172 \mathrm{~mm}$. TAWs of the study irrigation scheme is with the range of FAO (1985) recommendation for the particular soil type. 
Table 2. Selected soil physical characteristics of Wosha irrigation scheme.

Soil properties
Texture
FC $(\%)$
PWP $(\%)$
Bd $\left(\mathrm{g} / \mathrm{cm}^{3}\right)$
TAW $($ at $120 \mathrm{~cm})$

Field Location

\begin{tabular}{ccc}
\hline Head & Middle & Tail \\
\hline Clay & Sandy Load & Sand \\
37.2 & 24.4 & 13.1 \\
24.3 & 12.6 & 7.4 \\
1.04 & 1.22 & 1.25 \\
161 & 172 & 86 \\
\hline
\end{tabular}

\section{Technical Performance Indicators}

\section{Conveyance Efficiency (Ec) and Losses}

The result showed that the conveyance efficiency in the lined main canal of Wosha Irrigation Scheme is $92.3 \%$ (Table3). The current finding is in line with former reports of Gashaye and Tena (2008) who reported conveyance efficiency of Geray irrigation scheme as $92 \%$. On the other hand, the average conveyance efficiency in the unlined secondary canal wosha irrigation scheme was $60.2 \%$, this is due to loss through seepage loss in the side and bed of the earthen canals. Bayan (2017) reported a similar finding that unlined conveyance efficiency of Mada Batu small-scale irrigation scheme canals ranged from 47.1 to $88.6 \%$. In contrary, the conveyance efficiency in the main unlined canal of Midhegdu small-scale irrigation scheme was $88.8 \%$ as reported by Worku (2013). This might be due to the difference in soil property and structural stability of the earth canals.

Overall, the scheme has a conveyance efficiency of $55.6 \%$, which is very low efficiency recorded in the scheme due to the secondary canals are unlined. According to FAO (1989) reports, the conveyance efficiency for the earthen canal could be 80 and $95 \%$ for the lined canal; therefore, unlined canals of the scheme was under the desired efficiency.

Losses through the conveyance system, which is in the main and secondary canal at Wosha irrigation scheme, were 0.06 and $0.093 \mathrm{l} / \mathrm{s} / \mathrm{m}$, respectively. As per the field observation during field data collection in canals, the conveyance loss in the lined canal was due to linkage through division boxes. However, loss of irrigation water in the unlined canals associated with seepage losses. This was exacerbated by the flat slope of the canal, which leads to the higher contact surface and poor structural stability of earthen materials of the canals. The current finding is greater than the loss in the unlined canal of Mada Batu small-scale irrigation scheme, which is ranged from 0.02 1 to $0.04 \mathrm{l} / \mathrm{s} / \mathrm{m}$ as reported by Bayan (2017).

Table 3. Conveyance efficiency of the irrigation schemes

\begin{tabular}{ccc}
\hline Canal & Conveyance Efficiency $(\mathrm{Ec})(\%)$ & Conveyance losses $(1 / \mathrm{s} / \mathrm{m})$ \\
\hline Main & 92.3 & 0.060 \\
Secondary & 60.2 & 0.093 \\
\hline Scheme Ec & 55.6 & \\
\hline
\end{tabular}

\section{Application Efficiency (Ea)}

The study revealed that the average application efficiency of wosha irrigation scheme was 48.2 (Table 9). The efficiency has a trend of decreasing as it moves from head to tail of the scheme. This might be due to the physical property of the soil, which indicates that water-holding capacity at the head is better than at the middle and tail of the scheme. According to FAO (2002) reports, the application efficiency of furrow irrigation could range from 50 to $70 \%$. However, Wosha irrigation scheme was found to be below the range.

From mean application efficiency, the least contributed from the tail reach of the scheme it was because of typically the soil categorized in sand textural class with high deep percolation loss. According to Ayele (2016) report, the application efficiency of Guder irrigation scheme was nearly similar to Wosha irrigation scheme, which is $49.7 \%$.

Table 4. Application efficiency of wosha irrigation scheme.

\begin{tabular}{cccc}
\hline Field location & Applied depth $(\mathrm{mm})$ & Stored depth $(\mathrm{mm})$ & Ea (\%) \\
\hline Head & 100.2 & 59.9 & 59.7 \\
Middle & 86.9 & 45.2 & 52.0 \\
Tail & 71.3 & 23.4 & 32.8 \\
\hline Scheme average efficiency & & & 48.2 \\
\hline
\end{tabular}

\section{Storage Efficiency (Es)}

Water storage efficiency at Wosha irrigation scheme was varied $92.5 \%$ from head to $83.8 \%$ at the tail of the scheme and the maximum efficiency recorded in the middle of the scheme which is $93.2 \%$ whereas, the average storage efficiency was $89.8 \%$ (Table 5). Storage efficiency has the advantage to know the applied irrigation water is satisfied with the moisture deficit of the crop root zone. The result implies about $89.8 \%$ of the soil moisture deficit 
of both irrigation schemes satisfied. Farmers practiced water conservation techniques by mulching the soil with sugarcane straw. This helps them to stay without irrigation by minimizing evaporation loss for up to one to two months. The current finding is in line with Korkmaz and Avci (2012) who reported the storage efficiency varies from $54 \%$ to $97 \%$ over the scheme at Menemen Left Bank irrigation system.

Table 5. Storage efficiency of the irrigation schemes.

\begin{tabular}{cccc}
\hline Field Location & Stored water at root zone $(\mathrm{mm})$ & Required Water $(\mathrm{mm})$ & Es $(\%)$ \\
\hline Head & 59.9 & 64.7 & 92.5 \\
Middle & 45.2 & 48.5 & 93.2 \\
Tail & 23.4 & 27.9 & 83.8 \\
\hline \multicolumn{2}{c}{} \\
\hline
\end{tabular}

\section{Water Distribution Uniformity (DU)}

The computed result indicated that the average water distribution uniformity of wosha irrigation scheme was $91.7 \%$ (Table 6). In addition, the result revealed that water distribution uniformity at three reaches of the irrigation schemes has small variation from 90 to $93 \%$, which implies that the irrigated water distributed uniformity throughout the same. This is due to the sugar cane fields were lay-outed by keeping the farm leveled.

According to the recommendation of FAO (1992), the studied irrigation scheme had adequate irrigation water distribution over the entire farm field. The current finding revealed that distribution uniformity was above sufficient, in which 30 and $65 \%$ were taken as poor and sufficient, respectively (FAO, 1992). Similar findings were reported by many authors, in which the water distribution uniformity was greater than $90 \%$ (Bayan, 2017; Dessalew et al., 2016; Worku, 2013; Menelik, 2008). However, Dinka (2017) also reported conflicting results that average water distribution uniformity of the Ketar medium Scale irrigation Scheme was 61.6\% due to the scheme operating at flow rates below or above the design flow rates. This could lead to inefficient and non-uniform water distribution in the whole farm field.

Table 6. Water distribution uniformity of the irrigation schemes

\begin{tabular}{|c|c|c|c|}
\hline $\begin{array}{c}\text { Field } \\
\text { Location }\end{array}$ & $\begin{array}{c}\text { Mean stored } \\
\text { water }(\mathrm{mm})\end{array}$ & $\begin{array}{l}\text { least quarter mean } \\
\text { Stored water }(\mathrm{mm})\end{array}$ & DU $(\%)$ \\
\hline Head & 60.0 & 55.1 & 91.9 \\
\hline Middle & 45.2 & 42.2 & 93.2 \\
\hline Tail & 23.4 & 21.1 & 90.1 \\
\hline \multicolumn{2}{|c|}{ Scheme efficiency } & & 91.7 \\
\hline
\end{tabular}

\section{Deep Percolation Ratio}

The majority of water loss during every irrigation event was deep percolation as farmer practice ended tied furrow. The average schemes deep percolation loss was found as $51.8 \%$. The highest deep percolation loss recorded at the tail of the scheme as $67.2 \%$. In which the sandy property of the soil contributes to the lion share of the loss. The deep percolation ratio at the head and middle of Wosha irrigation scheme was 40.3 and $48.0 \%$ of the applied water, respectively (Table 7). According to FAO (1989), the water loss through deep percolation and surface runoff could be about $40 \%$ and above.

Table 7. Deep percolation ratio of the irrigation scheme.

\begin{tabular}{cccc}
\hline Field & Ea & Runoff ratio, & Deep percolation ratio, \\
location & $(\%)$ & RR $(\%)$ & DPR $(\%)$ \\
Head & 59.7 & 0 & 40.3 \\
Middle & 52 & 0 & 48 \\
Tail & 32.8 & 0 & 67.2 \\
\hline Scheme average efficiency & 48.2 & & 51.8 \\
\hline
\end{tabular}

\section{Overall Efficiency}

The study revealed that the overall efficiency of Wosha irrigation schemes was $26.8 \%$ (Table 8 ). This indicates that the scheme is performing with poor efficiency. Poor efficiency for the scheme was due to its poor application efficiency. The scheme overall efficiency was nearly similar to the overall efficiency of Dodicha irrigation scheme, which is $28.6 \%$ as reported by Eticha (2011).

According to Tesfaye et al. (2019) report the scheme is expanding the irrigated command area beyond the design capacity without modifying the amount of water diverted, in this regard efficient irrigation water management options should be introduced. 
Table 8. Overall scheme efficiency of the schemes

\begin{tabular}{cc}
\hline Internal indicator & Scheme efficiency (\%) \\
\hline Conveyance efficiency & 55.6 \\
Application efficiency & 48.2 \\
Storage efficiency & 89.8 \\
Distribution efficiency & 91.7 \\
Deep percolation ratio & 51.8 \\
\hline Overall scheme efficiency & 26.8 \\
\hline
\end{tabular}

\section{Conclusions and Recommendations}

The current study revealed that the overall performance of wosha irrigation scheme has performing in poor efficiency. According to the internal indicators, the application efficiency was very low due to losses through deep percolation during irrigation events. In addition, conveyance efficiency in the unlined section of the scheme was very low due to leakage loss. Storage efficiency and water distribution uniformity were in good condition. The deep percolation loss was greater in tail reaches of the irrigation scheme, moreover in the scheme. Poor application efficiency and high seepage loos in secondary canals were responsible for the lion share of low overall efficiency at Wosha Irrigation Scheme.

Generally, based on the evaluation carried in the irrigation scheme would need improvement measures to maximize the performance. Therefore, for the improvement of application efficiency deficit irrigation, surge and cutoff applications shall be adopted. Proper irrigation scheduling should be used because the application efficiency can be improved by applying the right depth of water in the right place at the right time. The conveyance efficiency can be improving through regular maintenance of the canals and water controlling metal sheet gates in the intake structures and conveyance systems especially in the division box. Finally, frequent performance evaluation should be conducted to identify the performance level of the scheme.

\section{REFERENCE}

Allen, R.G., Pereira, L.S., Raes, D. and Smith, M. 1998. Crop evapotranspiration guidelines for computingcrop water requirements. FAO irrigation and drainage 56. FAO-Food and Agricultural Organization of the United Nations, Rome, 1998.

Ayele Tebikew. 2016. Technical Performance Evaluation and Redesigning of Small-Scale Irrigation Scheme: Case of Guder Irrigation Scheme Awi Zone, Amhara Region. MSc. Thesis. Haramaya University.

Bayan Ahmed. 2017. Technical performance evaluation of Mada Batu small-scale irrigation scheme, West Arsi zone of Oromia Region. International Journal of Engineering Research-Online. Vol.5, Issue.3

Dessalew, T., Ayalew, A., Desalegn, T., Mathewos, M. and Alemu, G. 2016. Performance Evaluation of Bedene Alemtena Small Scale Irrigation Scheme in Hallaba Special Woreda, Southern Ethiopia. Open Access Library Journal, 3: e2021.

Dinka Fufa. 2017. Technical Performance Evaluation of Ketar Medium Scale Irrigation Scheme, Southeast of Oromia Regional State, Ethiopia. Civil and Environmental Research. 9 (9).

Eticha Shiberu. 2011. Performance Evaluation of Small Scale Irrigation Schemes in Adami Tullu Jido Kombolcha Woreda, Central Rift Valley of Ethiopia. MSc Thesis. Haramaya University.

FAO (Food and Agriculture Organization). 2002. Irrigation Manual: Planning, Development Monitoring and Evaluation of Irrigated Agriculture with Farmer Participation. Volume II Module 7. Harare.

FAO (Food and Agriculture Organization). 1992. CropWat: A Computer Program for Irrigation Planning and Management: Irrigation and Drainage Paper. No. 46. FAO, Rome.

FAO (Food and Agriculture Organization of the United Nations). 1989. Guidelines for designing and evaluating surface irrigation systems. Irrigation and Drainage Paper 45. FAO, Rome.

FAO (Food and Agriculture Organization). 1985. Institutional and Technical Options in the Development and Management of Small-Scale Irrigation. Proceeding of the third session of the Multilateral Cooperation Workshop for Sustainable Agriculture; Forestry and Fisheries Development, Tokyo Japan. FAO Water Paper, No. 17. Rome.

Feyene, J., and Dawit Zerihun. 1999. Assessment of the Performance of Border and Furrow Irrigation Systems and the Relationship between Performance Indicators and System Variables. Agricultural Water Management. 40: 353-362.

Gashaye Checkol and Tena Alamirew. 2008. Technical and Institutional Evaluation of Geray Irrigation Scheme in West Gojjam Zone, Amhara Region, Ethiopia. Journal of Spatial Hydrology Vol.8, No.1 Spring 
Harrelson, C. C., Rawlins, C. L. and Potyondy, John P. 1994. Stream channel reference sites: an illustrated guide to field technique. Gen. Tech. Rep. RM-245. Fort Collins, CO: U.S. Department of Agriculture, Forest Service, Rocky Mountain Forest and Range Experiment Station. 61 p.ILRI, The Netherlands.

Ingle, P. M., Shinde, S. E., Mane, M. S., Thokal, R. T. and Ayare, B. L. 2015. Performance Evaluation of a Minor Irrigation Scheme. Research Journal of Recent Sciences. 4: 19-24.

Jaiswal, P. C. 2003. Soil, Plant and Water Analyses. Ludhiana Kalyani publishers. New Delhi, India.

Menelik Hailu. 2008. Performance Evaluation of Small-Scale Irrigation Scheme: A Case Study of Selgie Irrigation Scheme, South Wollo. M.Sc. Thesis. Haramaya University.

Michael, A. M. 2008. Irrigation theory and Practice, Second edition VIKAS Publishing house Pvt Ltd. India.

Pereira, L.S., Cordery, I. and Iacovides, I. 2009. Coping with water scarcity: Addressing the challenges. Springer Science Business Media B.V. Paris, France.

Seleshi Bekele, Aster Denekew, Mekonnen Loulseged, Loiskandl, W., Mekonne Ayana, Tena Alamirew. 2007. Water Resources and Irrigation Development in Ethiopia. Colombo, Sri Lanka: International Water Management Institute. 78p. (Working Paper 123)

Seleshi Bekele. 2010. Irrigation potential in Ethiopia; Constraints and opportunities for enhancing the system. International Water Management Institute. Addis Ababa, Ethiopia.

Tesfaye HC, Dananto M, Woldemichael A (2019) Comparative Performance Evaluation of Irrigation Schemes in Southern Ethiopia. Irrigat Drainage Sys Eng 8: 232. doi: 10.4172/2168-9768.1000232

USBR. 2014. Parshall flumes-United States Bureau of Reclamation. http:/www.usbr.gov/pmts /hydraulics lab/pubs/wmm/chap08 10.html.

Walker, W. R. 2003. SIRMOD III: Surface irrigation simulation, evaluation and design. Guide and Technical Documentation. Utah State University, USA.

Worku Negussie. 2013. Technical Performance Evaluation of Midhegdu Small-scale Irrigation Scheme in West Hararge Zone, Oromia Region, Ethiopia. M.Sc. Thesis. Haramaya University.

WWAP (United Nations World Water Assessment Programme). 2012. The United Nations World Water Development Report 4. Managing Water under Uncertainty and Risk. UNESCO, Paris.

Zeleke Agide., Schultz, B. and Hayde, L. 2012. Comparative irrigation performance assessment in community-managed schemes in Ethiopia. African Journal of Agricultural Research Vol. 7(35): 4956-4970. 